\title{
COVID-19 Impact on Market Capitalization in GCC
}

\author{
Ghias ul Hassan Khan \\ Department of Accounting \\ College of Business Administration \\ University of Bahrain \\ ghiasacca@gmail.com \\ ghkhan@uob.edu.bh
}

\begin{abstract}
The purpose of this scholarly article is to provide information related to the need and indicators of goodwill impairment when it needs to be tested. This paper also here discusses the increasing number of COVID-19 active cases concerning its overall market capitalization in GCC countries evidenced from respective stock exchanges. A further area for more research left here related to the investigation of decreasing and increasing trends in the market capitalization linked with the COVID-19 pandemic.
\end{abstract}

Keywords: COVID-19, Market capitalization, Impairment, and Goodwill

\section{Introduction}

COVID-19 pandemic plays a vital role with its unknow prevailing duration in the volatility and uncertainty of the market capitalization towards the declining curve in the very start of the period of a sudden increase in the number of active cases, but later the market was recovering which reflects the panic controlling phenonium but this may bring a notable impact on goodwill in business sectors in any direction. Along with many other factors, this will also lead to the emergent need of testing the goodwill for impairment. But this will not equally affect every company at the same pace, because the hypothesis of change and the impacts on market demand with the shift in customer preferences will vary according to the nature and need of the product as well as the financial strength of the company for sustainability will differ. But ultimately the merging effect of COVID-19 and the overall uncertainty harm goodwill if the situation will not properly and positively be managed by the companies.

Goodwill is an intangible asset, which we cannot be touch but feels that it has a major role in generating sustainable growth in earnings. In the accounting world, we come across two types of goodwill estimations the one which is called internally generated and the other is purchased one. The valid and acceptable type in accounting treatments for recording purposes as per the accounting standards is the purchase one. Purchased goodwill is associated with the purchase of one company by another.

"The value of a company's brand name, solid customer base, good customer relations, good employee relations, and proprietary technology represents some reasons why goodwill exists." (Marshall 2020)

Impairment of goodwill means, drop in the market value of the company below to its historical cost. According to the various standards prevailing in the different parts of the world like (US GAAP - FAS 142, UK GAAP FRS 10 and IFRS 3 - Business Combination) required that goodwill should go through annually with the impairment test instead of amortizing over a certain number of years as it has an indefinite life).

"Goodwill now passed from being a wasting asset to be amortized to an asset be annually tested for impairment". (Denel Pierre, 2019)

Before adopting the process of impairment, we must have to consider whether any impairment indicator exists, or any other major event occurs which negatively triggers the market value of the company. In this article, the market capitalization for an overall sector concerning the COVID-19 period is used as a basis for the hypothesis that in the current pandemic due to the probable adverse effects on profitability harm market capitalization which indicates that there is a need to test goodwill for impairment. 


\section{Background}

The world always faces challenges of different and this is not the first time that the world facing such type or naturerelated problems in terms of the pandemic which is in discussion nowadays very frequently in industries as well as everywhere.

There are different symptoms of health issues converting in diseases according to the intensity and complexity of the human body. Disease-causing influenza, respiratory disorder, congestion, breathing stiffness, flu, and like symptoms in past decades also encountering by the world such as follows.

1. 1976 - Ebola virus

2. $2002-2004$ outbreak - Severe acute respiratory syndrome - (SARS coronavirus)

3. 2009 - 2010 - Swine influenza pandemic - (H1N1)

4. 2013 - Avian influenza- (H7N9) and

5. Currently COVID-19

Fan (2003) during the period of the virus named SARS because of shaken the customers' confidence it reduces the demand for products which results in declining the economic growth in many countries affecting by it. The main cause of this impact is the fear of strengthening in people's minds due to the pandemic lie currently also we are facing such a scenario. People make their minds and decided to stay safe at home to reduce the likelihood and pace of spread that virus. In addition to it also export and the tourism industry have drastic negative impacts due to the prevailing pandemic situation in that current period.

Verikios (2011) in 2009 when the H1N1 pandemic which is swine influenza hit the areas of the economy and as it also notably impact negatively in the education sector as well as drastically impact on specific sectors' economic conditions about the tourism, transport retail, etc. Businesses due to a reduction in consumption for staying home by consumer experiencing declining curve in growth as shown in the figure concerning the percentage loss to baseline GDP sectorwise.

Qiu (2018) comparatively concerning the SARS pandemic, Avaian Influenza (H7N9) has a much lesser adverse impact on the economy in terms for reduced demand as it is only confined to the poultry and meat consumption as a precautionary measure, that is why it was less severing in adverse impact which mainly affects the poultry industry with no other major industries as far as the economic scale in concern.

Overall the impact in different scenarios usually impacting the business which will affect market capitalization if not controlled appropriately. This impact will last permanently but also it hasa temporary effect if controlled in the right way and taking precautions at the government level.

\section{Literature Review}

Accountancy Europe PwC (2020) currently the COVID-19 pandemic spreading and hitting the countries in the world one by one which also negatively impact organizations in terms of the reduced level of production due to fall in economic demand and consumption. The impact of COVID-19 is not only confined to the reduced consumption, demand or economic downfall as previously mentioned pandemics showed. It also has notable consequences of accounting,

Auditingand management aspects. This makes it necessary to do required accounting changes and applications as per the IFRS emergent clauses. The board of a company needs to be taken this seriously and consider the impacts of this outbreak to impart the IFRS issues in financial statements at both the interim and annual stages. This will lead as an indirect but several impacts from reduced economic activities and the organization should have to take account of its areas which affect considerably.

Parker Russel Intl. (2020) companies need to consider the major impacts of COVID-19 on potential risk areas and uncertainties. The continuous increase in cases and negative economic conditions may create a need for impairment test and most probably need further impairment in carrying values of assets and obligations especially in terms of leases which turning burdensome and required to include this in disclosures.

IFRS in Focus (April 2020) Organizations should take into careful consideration their distinctive conditions and their exposition to risks when they analyze how the current proceedings can impact their financial reporting. More particularly, financial reporting and its related disclosure in the financial statement need to communicate all material current or potential impacts of COVID-19. Likewise, it is of utmost importance that the management understands the risks that its organization is dealing with in addition to how these risks can impact the management. 
IFRS in Focus (May 2020) As a result if increasing this pandemic in both magnitude and duration, corporations and other businesses are facing conditions of overall economic downstream. It is not only confined to the financial market attrition, credit clash, liquidity issues but more to increase government intervention in a result of which increase in unemployment due to lockdowns and it considerably reduces the consumer discretion on consumption which could have a prolonged negative impact on an entity's financial results.

This case study discusses certain key IFRS accounting considerations related to conditions that may result from the COVID- 19 pandemic. Although individual issues discussed here will of course vary by industry and by the entity, but as believe that the topics mentioned in the discussion section will be the most pervasive concerning the current situation.

\section{Figures and Tables}

Below mentioned tables below show the facts and impact of COVID-19 active cases on market capitalization at the overall level under the period from February to April 2020.

TABLE 1

\begin{tabular}{|l|r|r|r|r|r|r|}
\hline \multicolumn{2}{|l|}{ COIVD-19 ACTIVE CASES (End of Month) } \\
\hline & Bahrain & \multicolumn{1}{|l|}{ KSA } & UAE & Oman & Kuwait & Qatar \\
\hline February & 38 & 7 & 21 & 6 & 45 & 1 \\
\hline March & 567 & 1,563 & 664 & 192 & 289 & 835 \\
\hline April & 3,040 & 22,753 & 12,481 & 2,348 & 4,024 & 14,096 \\
\hline
\end{tabular}

TABLE 2

\begin{tabular}{|l|r|r|r|r|r|r|}
\hline \multicolumn{7}{|l|}{ CHANGE IN MARKET CAPITALIZATION (End of Month) in \%age } \\
\hline & \multicolumn{1}{|c|}{ Bahrain } & \multicolumn{1}{l|}{ KSA } & UAE & \multicolumn{1}{l|}{ Oman } & \multicolumn{1}{l|}{ Kuwait } & \multicolumn{1}{l|}{ Qatar } \\
\hline January & 2.99 & -3.06 & 3.05 & 17.16 & 0.86 & -0.56 \\
\hline February & 0.17 & -3.71 & -4.14 & -12.66 & -5.22 & -9.23 \\
\hline March & -18.65 & -10.25 & -19.81 & -14.33 & -22.77 & -12.44 \\
\hline April & -2.96 & 5.86 & 14.24 & 1.81 & 3.08 & 7.23 \\
\hline
\end{tabular}

\section{Discussion}
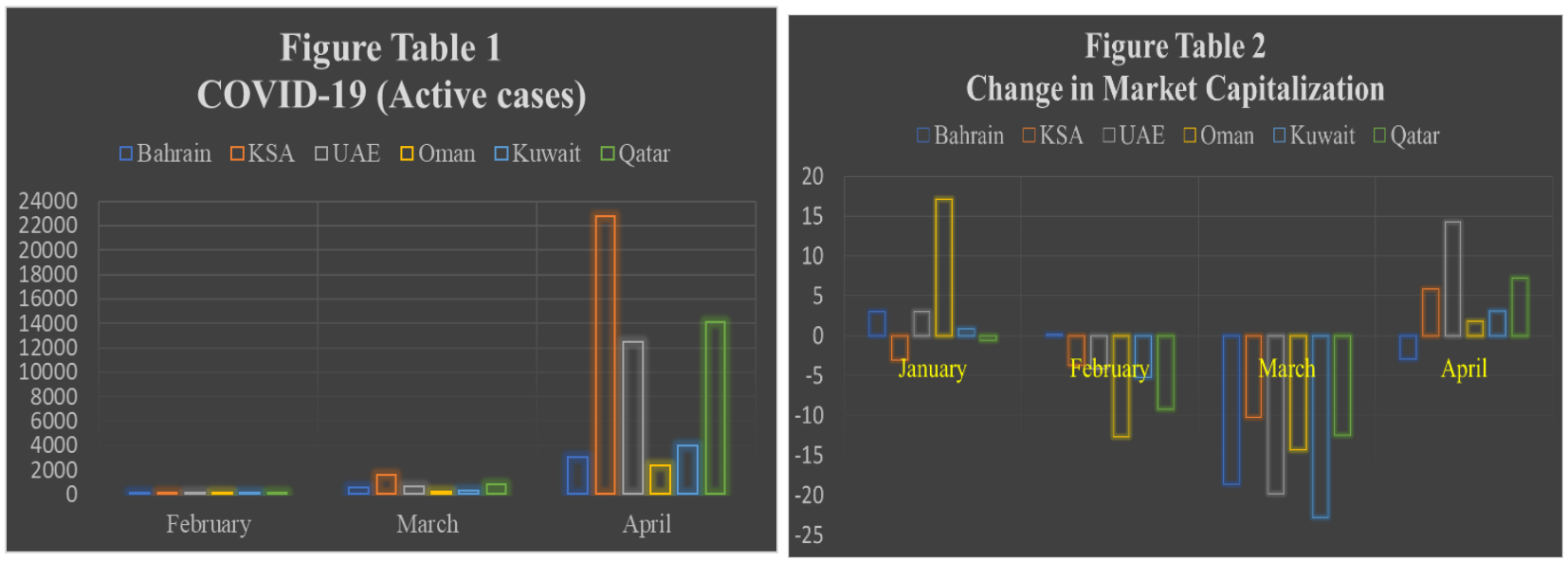

The information presented in the above table's shows that the number of COVID-19 cases a notable start comes in the market from February 2020. Initially highest in Bahrain due to the travelers' history but the market is still positive even showing a decline from 2.99 to 0.17 but in the case of other GCC countries it brought down to negative which shows the volatility of the market with the efficiency of information, and in KSA this still in negative from January which indicates that were some other issues also have an impact in this market. 
But in March when cases become drastically increase it creates a panic in the market which results in the huge decline in the market overall in all GCC, but as we can see that in April although the cases increased extraordinarily and surprisingly market capitalization shows recovery which can be seen in below-mentioned graphs as well above tables as a positive change except in

Bahrain which is still negative but improving from negative $18.65 \mathrm{t}$ negative 2.96 which shows a recovering trend. This is because of the control over the market panic and exploring the other ways of carrying business operations by the companies within the pandemic situation.

\section{Other Impairment Indicators}

Some factors can be taken as the need for goodwill impairment test (PJ Patel 2020)

1. A decline in company share price and market cap

2. Operating or cash flow loss in the current period

3. Change in the extent or manner of asset use

4. An adverse change in the legal or business climate

5. Capital and financial resource changes, including liquidity risk

6. A decrease in an asset's market value

7. Production slowdowns or shutdowns

8. Permanent or temporary store closures (yours or your competitors)

9. Workforce shortages/reductions

10. Drop-in competitor market multiples

11. Disruptions in the supply chain

12. Well below forecast earnings expectations or downward quarter-by-quarter revisions

13. Projected cash flow losses or net losses

\section{Conclusion}

It is quite clear from the above both tables that the pandemic effect is temporary as negative on market capitalization because of the sudden state of panic among the market forces and the enforcement of market and business lockdowns, but later on, it shows positive change except in the case of Bahrain which overall reflects that when the state of panic comes under control the businesses and other forces explore and implement other ways of carrying their activities like online orders, free delivery, online education and another medium of activities. This makes stabilizing the situation of the market even with the huge increase in the number of active cases and this leads to the positive change in market capitalization which can be seen in April compared with the March as reflect in the above table 2.

\section{References}

Pierre, Denel \& Guillaume, Oris. (2019). The Accounting Treatment of Goodwill: When will FASB Stop Changing the Rules? International Journal of Finance \& Economics. 4. 520-534.

Financial Accounting Standards Board. "Identifiable Intangible Assets and Subsequent Accounting for Goodwill," Accessed Jan. 21, 2020.

Fan, E. X. (2003). SARS: Economic Impacts and Implications. Asian Development Bank. ERD Policy Brief No. 15. Retrieved from https://www.adb.org/publications/sars-economic-impacts-and-implications

Verikios, G., Sullivan, M., Stojanovski, P., Giesecke, J., \& Woo, G. (2011). The Global Effects of Pandemic Influenza. Paper prepared for the 14th Annual Conference on Global Economic Analysis, Venice, June 16-18, 2011. Retrieved from https://static.rms.com/email/documents/liferisks/papers/the-global-economic-effects-ofpandemicinfluenza.pdf

Qiu, W., Chu, C., Mao, A., \& Wu, J. (2018). The Impacts on Health, Society, and Economy of SARS and H7N9 Outbreaks in China: A Case Comparison Study. Journal of Environmental and Public Health, 7, 1-7 https://doi.org/10.1155/2018/2710185

Accountancy Europe. (2020). Coronavirus Crisis: Implications of Reporting and Auditing. Retrieved March 20, 2020, fromhttps://www.accountancyeurope.eu/publications/coronavirus-crisis-implications-on-reportingandauditing/

Parker Russell International. (March 2020). The Impact of COVID-19 on Financial Reporting. Retrieved from https://www.parkerrussellinternational.com/wp-content/uploads/2020/03/ THE-IMPACT-OF-COVID-19-ONACCOUNTS.pdf

IFRS in Focus. (7 April 2020). Accounting Considerations Related to Coronavirus Disease in 2019. Deloitte Publications. Retrieved from https://www.iasplus.com/en/publications/global/ifrs-in-focus/2020/coronavirus 
IFRS in Focus. (May 2020). Accounting Considerations Related to Coronavirus Disease in 2019. Deloitte Publications. Retrieved from.

file://D:/RESEARCH\%20SECTION/Gathered\%20data/Covid\%2019\%20\&\%20Accounting/IFRS\%20in\%20Focus\%2 0-\%20COVID-19\%20-\%204\%20May\%20Update\%20(1).pdf

\section{Other web-references}

https://www.financialexecutives.org/FEI-Daily/April-2020/Goodwill-Impairment-in-the-COVID-19-Environment.aspx https://www.investopedia.com/terms/g/goodwill.asp https://www.financialexecutives.org/FEI-Daily/May-2020/Triggering-Event-Impacts-and-Impairment-Testing-in.aspx https://www.bahrainbourse.com/monthly-bulletin https://www.tadawul.com.sa/wps/portal/tadawul/markets/reports-\%26-publications/periodical-publications?locale=en https://www.adx.ae/English/Pages/MediaCenter/Publications/default.aspx https://www.msm.gov.om/downloads.aspx?b1=Publications\&b2=Monthly$\% 20$ Publication $\% 20$ s\&c $\% 20=\% 205 \% 20 \& \% 20$ ti $\% 20=\% 20$ Monthly-Publications https://www.qe.com.qa/qe-publications https://en.m.wikipedia.org/wiki/COVID-19 pandemic in_Saudi_Arabia https://en.m.wikipedia.org/wiki/COVID-19_pandemic_in_Oman https://en.m.wikipedia.org/wiki/COVID-19_pandemic_in_the_United_Arab_Emirates

https://en.m.wikipedia.org/wiki/COVID-19 pandemic in Bahrain https://en.m.wikipedia.org/wiki/COVID-19_pandemic_in_Qatar https://en.m.wikipedia.org/wiki/COVID-19 pandemic in Kuwait 